\section{A Method for sampling Arthropods and Molluscs from Herbage by Suction}

THE insect population in herbage, for example, in rough grassland, is commonly sampled by sweeping. Other arthropods such as mites, centipedes, millipedes and also slugs and snails are obtained by trapping, hand-picking, or by removing part of the habitat for extraction in the laboratory. We have developed a new, more universal method, liable to less personal error than sweeping, which extracts a very high proportion of small invertebrates from rough matted grassland with a suction pump. There is no need to remove a part of the habitat, and the method could be applied widely.

The apparatus is a portable electric blower (Type N.W.B.E.) as supplied by Wolf Electric Tools, Ltd., London, and run on the mains supply. A metal barrel (10 in. long, $5 \cdot 5$ in. diam.) is attached to the intake, and on the lid of this barrel is a flexible hose ending in a hard rubber nozzle with a 1 -in. aperture. A nylon collecting bag fits inside the barrel and is kept in place by the lid. The apparatus weighs $15 \cdot 5 \mathrm{lb}$., and is easily carried.

For sampling, a metal cylinder 12 in. $\times 12$ in. is pressed into the grass, the apparatus is switched on and the nozzle worked back and forth over the area within the cylinder. Two successive extractions each of two minutes with a two-minute interval between were found to be satisfactory. Table 1 shows the extraction-rates based on this procedure and on the numbers remaining behind in the herbage and in the upper few millimetres of soil within the metal cylinder (these being sorted by hand from the material brought back to the laboratory). From approximately 23 sq. ft., 2,945 insects, 1,606 other arthropods and 189 molluses were extracted.

\begin{tabular}{|c|c|c|c|}
\hline Group & $\begin{array}{c}\text { Mean } \\
\text { extraction } \\
\text { (per cent) }\end{array}$ & Group & $\begin{array}{c}\text { Mean } \\
\text { extraction } \\
\text { (per cent) }\end{array}$ \\
\hline $\begin{array}{l}\text { Collembola- } \\
\text { (Arthropleona) } \\
\text { Collembola } \\
\text { (Symphypleona) } \\
\text { Thysanoptera } \\
\text { Auchenorhyncha } \\
\text { Aphidoidea } \\
\text { Heteroptera } \\
\text { Staphylinidae } \\
\text { Ptillidae } \\
\text { Other Cole- } \\
\text { optera }\end{array}$ & $\begin{array}{r}99 \cdot 3 \\
100 \cdot 0 \\
97 \cdot 5 \\
98 \cdot 1 \\
99 \cdot 8 \\
98 \cdot 9 \\
92 \cdot 2 \\
97 \cdot 4 \\
92 \cdot 5\end{array}$ & $\begin{array}{l}\text { Coleoptera (larvæ) } \\
\text { Hymenoptera } \\
\text { (Parasitica) } \\
\text { Diptera (adults) } \\
\text { Diptera (larvæ and } \\
\text { pupæ) } \\
\text { Isopoda } \\
\text { Acarina } \\
\text { Araneida } \\
\text { Diplopoda } \\
\text { Chilopoda } \\
\text { Mollusca }\end{array}$ & $\begin{array}{l}70 \cdot 3 \\
97 \cdot 0 \\
99 \cdot 2 \\
75 \cdot 5 \\
98 \cdot 3 \\
90 \cdot 2 \\
97 \cdot 4 \\
86 \cdot 1 \\
66 \cdot 7 \\
94 \cdot 7\end{array}$ \\
\hline
\end{tabular}

We shall be glad to supply further information. Full details will be published elsewhere.

$$
\begin{gathered}
\text { C. G. JoHNSON } \\
\text { T. R. E. SoUTHWOOD } \\
\text { H. ENTwISTLE } \\
\text { Rothamsted Experimental Station, } \\
\text { Harpenden, Herts. }
\end{gathered}
$$

\section{A Water-soluble Filter for trapping Airborne Micro-organisms}

IN studies of airborne mould spores as a cause of respiratory allergy, there has been a need for a trap which would not only sample the air efficiently out of doors and give a measure of the number of spores per unit volume of air, but which would also allow the spores to be grown on culture media for identification.
Preliminary experiments early in 1952 indicated that a water-soluble 'wool' of sodium alginate could be used to trap spores. The sodium alginate is not available as a wool but has to be prepared from calcium alginate yarn. Initially yarns of four weights were tried $(450 / 160 ; 150 / 60 ; 100 / 27$; and $50 / 12$, denier/filament (continuous), $Z$ twist), but the most uniformly textured wool was produced by the 50 denier $/ 12$ filament yarn (from Messrs. Courtaulds, Ltd., Use-Development Organisation, 15 Cross Street, Manchester 2).

The calcium alginate yarn is cut into short lengths $(5-10 \mathrm{~mm}$.) and stirred into a relatively large volume of water to allow the yarn to untwist to its constituent filaments, then drained on a Buchner funnel. The resultant mass (calcium alginate 'wool') is soaked in hydrochloric acid (approximately $N$ ) until all calcium has been leeched out. (Test for removal of calcium by allowing a few drops of the acid solution to drip into a solution of ammonium oxalate - no precipitate indicates calcium removed.) The yarn is again drained off, suspended in 50 per cent alcohol and neutralized with sodium hydroxide. (Allow time for the strands in the centre of the mass to react with the alkali.) The yarn is now sodium alginate and is soluble in water. It receives several washes in 50 per cent alcohol, a final wash in absolute alcohol and is dried at room temperature. Best results are obtained by using throughout relatively large volumes of the suspending liquids, so that the alginate strands are always loosely suspended. The final product appears much like a wad of cotton wool, but it is soluble in water up to 1 part in 10 at room temperature. Tha higher concentrations are very viscous; but a 2 per. cent solution in water has a viscosity about four times that of water, and a 1 per cent solution only about 1.5-2 times the viscosity of water. The wool may be sterilized dry at about $125^{\circ} \mathrm{C}$.

The sodium alginate wool has been used for trapping airborne micro-organisms in the following way. The filter holder is a cylindrical brass tube $75 \mathrm{~mm}$. long, $12 \mathrm{~mm}$. diameter and $11 \mathrm{~mm}$. bore. At one end the wall is bevelled on the outside to a sharp edge which during sampling is directed into the wind. Fixed transversely across the bore of the tube, $25 \mathrm{~mm}$. from this sharp end, is a pair of crossed wires providing support for the alginate plug, which is rammed in at this end. (About $0.5 \mathrm{gm}$. of the wool packs into a plug approximately $10 \mathrm{~mm}$. long, which is more than adequate.) The other end of the tube is connected to a pump. When the desired volume of air has been sucked through the plug, it is pushed out into sterile water which, after complete solution of the plug, is made up to the desired volume. Aliquots of this solution are plated out on culture media for incuba. tion and counting.

For taking samples over several hours at the regular trapping site at St. David's Hospital, Cardiff, a windvane mounting similar to that described by Hirst ${ }^{1}$ has been used for maintaining the sharp end of the filter tube facing the wind. The rate of suction through the filter is controlled at the mean wind velocity recorded at the site by a Casella three-cup anemometer, and thus sampling is approximately isokinetic ${ }^{2}$.

To evaluate the efficiency of the plug in filtering off micro-organisms, several runs were made in which air after passing through the alginate plug was immediately bubbled through dilute agar solution. All this solution was plated out on media and incubated. These plates almost invariably remained sterile. 